\title{
Responses of Flowering Time to Elevated Carbon Dioxide among Soybean Photoperiod Isolines
}

\author{
James A. Bunce ${ }^{1,2}$, Wilbert Cruz Hilacondo ${ }^{1,2}$ \\ ${ }^{1}$ USDA-ARS Crop Systems and Global Change Laboratory, Beltsville, MD, USA \\ ${ }^{2}$ Instituto Nacionale de Innovacion Agraria, La Molina, Peru \\ Email: James.Bunce@ars.usda.gov, wcruz@inia.gob.pe
}

Received 26 February 2016; accepted 16 April 2016; published 19 April 2016

Copyright (C) 2016 by authors and Scientific Research Publishing Inc.

This work is licensed under the Creative Commons Attribution International License (CC BY).

http://creativecommons.org/licenses/by/4.0/

(c) †) Open Access

\begin{abstract}
Changes in the phenology of flowering in soybeans caused by long-term growth at elevated $\mathrm{CO}_{2}$ may be important to the responses of seed yield to elevated $\mathrm{CO}_{2}$. Here we utilized near-isogenic lines of soybeans differing in three genes influencing photoperiod sensitivity to determine whether these genes affected the response of flowering time to elevated $\mathrm{CO}_{2}$. Six isolines of Harosoy 63 were grown at ambient $\left(380 \mu \mathrm{mol} \cdot \mathrm{mol}^{-1}\right)$ and elevated $\left(560 \mu \mathrm{mol} \cdot \mathrm{mol}^{-1}\right) \mathrm{CO}_{2}$ concentrations in the field using free-air $\mathrm{CO}_{2}$ enrichment systems, in air-conditioned glasshouses with natural summer photoperiods, and in indoor chambers with day lengths of 11, 13, 15, and 17 hours. The effect of $\mathrm{CO}_{2}$ concentration on flowering time varied with genotype, and there was also an interaction between $\mathrm{CO}_{2}$ and photoperiod in all genotypes, as indicated by ANOVA. Elevated $\mathrm{CO}_{2}$ accelerated flowering in some cases, and delayed it in other cases. For all three of the isolines with single dominant genes, elevated $\mathrm{CO}_{2}$ decreased the days to first open flower at the longest photoperiod. At the shortest photoperiod, elevated $\mathrm{CO}_{2}$ delayed flowering in all but one isoline. The all-recessive isoline had slower flowering at elevated $\mathrm{CO}_{2}$ at both the shortest and the longest photoperiods, and also in the field and in the glasshouse. Delayed flowering at elevated $\mathrm{CO}_{2}$ in the field and glasshouse was associated with an increased final number of main stem nodes. It is concluded that the E1, E3, and $\mathrm{E} 4$ genes each influenced how the time to first flowering was affected by $\mathrm{CO}_{2}$ concentration at long photoperiods.
\end{abstract}

\section{Keywords}

Carbon Dioxide Concentration, Flowering, Soybean, Photoperiod, Isolines 


\section{Introduction}

Some experiments growing soybeans at different carbon dioxide concentrations have indicated that carbon dioxide concentration may affect the time of initial flowering (reviewed in Ellis et al. 1995). In some cases first flowering was earlier at elevated than at lower carbon dioxide, while the opposite response occurred in some other cases [1] [2]. No change has also been found in other cultivars. Comparisons of soybean cultivars at ambient and elevated carbon dioxide both in indoor controlled environment chambers and in the field indicated that the duration of vegetative growth, as affected by flowering phenology, was a significant source of variation in the stimulation of yield by elevated carbon dioxide [1]. Thus adaptation of soybeans to rising atmospheric carbon dioxide may benefit from a better understanding of carbon dioxide effects on flowering.

Both delaying and accelerating effects of elevated carbon dioxide on the time to first flowering have been found in several species in addition to soybean [3]. In some, but not all cases, faster flowering at elevated carbon dioxide could be attributed to a generalized acceleration of development as indicated by increased rates of leaf initiation [3]. In this work we tested for carbon dioxide effects on leaf initiation rate in soybean. However, acceleration of development at elevated carbon dioxide would not account for any delayed flowering at elevated carbon dioxide.

In soybeans, long photoperiods delay flowering in photoperiodically sensitive genotypes, and several different genes influencing the photoperiodic response of flowering have been identified [4] [5]. In the cultivar Harosoy 63, near isogenic lines ("isolines") of dominant and recessive combinations of the photoperiod sensitive genes E1, E3, and E4 had been previously developed [6], and were used in these experiments in order to determine whether any of these three genes caused elevated carbon dioxide concentration to affect the timing of flowering. Tests were conducted in the field, using free-air carbon dioxide enrichment systems, and in indoor chambers using a range of constant photoperiods at constant temperature. Additional tests were conducted in air conditioned glasshouses, with a typical planting date for soybeans at Beltsville, Maryland, USA, so that plants were exposed to a real, naturally varying photoperiod at constant temperature.

\section{Materials and Methods}

Six near-isogenic lines of Harosoy 63 (Table 1) were used in this study. Details of the origin of these isolines are given in [6]. The E1e3E4 isoline did not flower in the field or glasshouse experiments by the time flowering had ceased in all the other isolines (60 days after planting), so was not included in the indoor experiments with the two longest photoperiods.

In one experiment, five pots of each isoline were planted in each of two identical, unshaded, air conditioned glasshouses on June 3, 2014. The glasshouses were set to a constant temperature, and shaded, ventilated air temperatures were recorded every 15 minutes. The mean air temperature was $25.2^{\circ} \mathrm{C}$ in the ambient $\mathrm{CO}_{2}$ glasshouse and $25.3^{\circ} \mathrm{C}$ in the elevated $\mathrm{CO}_{2}$ glasshouse. The $\mathrm{CO}_{2}$ concentration in both glasshouses was continuously measured using infrared gas analyzers (WMA-4, PP Systems, Amesbury, MA) which were calibrated weekly. The $\mathrm{CO}_{2}$ concentration was uncontrolled in one glasshouse, and a vent was left open so that the $\mathrm{CO}_{2}$ concentration inside did not deviate by more than $10 \mu \mathrm{mol} \cdot \mathrm{mol}^{-1}$ from that of outside air. Pure $\mathrm{CO}_{2}$ was added to the other glasshouse to keep it $180 \pm 10 \mu \mathrm{mol} \cdot \mathrm{mol}^{-1}$ above that of the glasshouse without $\mathrm{CO}_{2}$ control, using a PID controller operating a solenoid valve. Typical daily time-courses of $\mathrm{CO}_{2}$ concentration are given in Figure 1, although the ambient night time $\mathrm{CO}_{2}$ concentration varied greatly with outside wind speed. The mean $\mathrm{CO}_{2}$ concentration in the ambient glasshouse was $416 \mu \mathrm{mol} \cdot \mathrm{mol}^{-1}$, and it was $596 \mu \mathrm{mol} \cdot \mathrm{mol}^{-1}$ in the elevated glasshouse. Seeds were sown in 2 liter plastic pots filled with peat moss, and were watered once or twice daily, and fertilized with a slow-release complete fertilizer. Seedlings were thinned to one per pot a few days after emergence. Flowering stages [7] were routinely recorded three times per week, and daily at critical stages of development, until flowering had ceased in all except the E1e3E4 isoline, which had not yet flowered. In addition to the flowering stages identified by Fehr et al. [7], the time of first open flower at the apical mainstem node was recorded for each plant. After all flowering and leaf initiation had ceased, the total number of mainstem nodes was determined for each plant. ANOVA was used to compare the mean values of the five plants per line in each glasshouse, recognizing that this was pseudo-replication.

In 2015, all the isolines were grown in field plots in Beltsville, Maryland at ambient (approximately 400 $\mu \mathrm{mol} \cdot \mathrm{mol}^{-1}$ during midday) and elevated (ambient $+180 \mu \mathrm{mol} \cdot \mathrm{mol}^{-1}$ ) $\mathrm{CO}_{2}$ concentrations, using an area distributed free-air carbon dioxide enrichment system [1]. The midday $\mathrm{CO}_{2}$ concentrations in the field plots averaged 
Table 1. Near-isogenic lines of Harosoy 63 used in these $\mathrm{CO}_{2}$ studies. PI is the identification number in the USDA-ARS Germplasm Resources Information Network system.

\begin{tabular}{cccc}
\hline Name & Genotype & Line designation & PI \\
\hline Harosoy 63 $^{\mathrm{a}}$ & e1E3E4 & L59-731 & 547,677 \\
Harosoy-e3 $^{\mathrm{b}}$ & e1e3E4 & L62-667 & 547,716 \\
Harosoy-e4 & e1E3e4 & OT94-41 & 591,435 \\
Harosoy-e3e4 & e1e3e4 & OT89-5 & 546,043 \\
Harosoy-E1e3e4 & E1e3e4 & OT93-28 & 591,430 \\
Harosoy-E1e3 & E1e3E4 & L71-802 & 547,747 \\
\hline
\end{tabular}

${ }^{\mathrm{a}}$ Harosoy 63 is e1e2E3E4e5Dt1 [4]; ${ }^{\mathrm{b}}$ Only substituted alleles are indicated in the name.

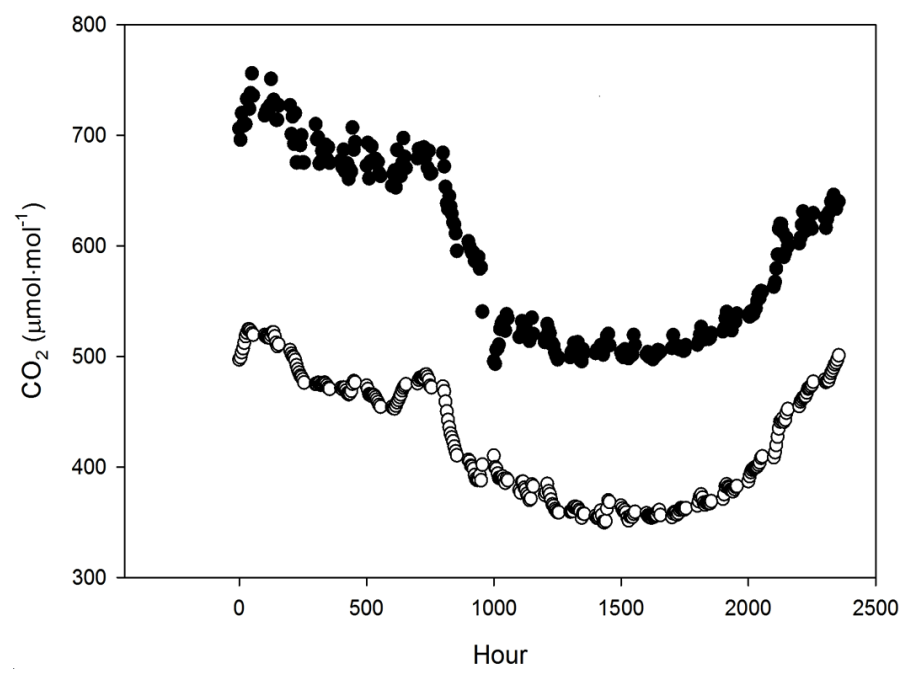

Figure 1. Typical daily time courses of $\mathrm{CO}_{2}$ concentration in uncontrolled (open symbols) and elevated (filled symbols) air conditioned glasshouses.

$388 \mu \mathrm{mol} \cdot \mathrm{mol}^{-1}$ for the ambient treatment and $572 \mu \mathrm{mol} \cdot \mathrm{mol}^{-1}$ for the elevated treatment. The elevated $\mathrm{CO}_{2}$ treatment was applied $24 \mathrm{~h}$ per day from planting. There were 3 replicate plots per $\mathrm{CO}_{2}$ treatment, with all isolines grown in each plot. Plots were planted on May 28, 2015. Flowering stages were monitored daily during crucial stages on five plants per plot. Final mainstem node number was determined at maturity. ANOVA was used to compare the two $\mathrm{CO}_{2}$ treatments for each line, with $\mathrm{n}=3$ plot replicates.

The isolines were also grown in indoor chambers with constant photoperiods of 11, 13, 15, and 17 hours. The total light per day therefore varied with photoperiod, which is also what occurs under field conditions. Air temperatures were constant at $25^{\circ} \mathrm{C}$, and relative humidity was $60 \%$. Daytime $\mathrm{CO}_{2}$ concentrations of 380 or 560 $\mu \mathrm{mol} \cdot \mathrm{mol}^{-1}$, and night time concentrations of 420 and $600 \mu \mathrm{mol} \cdot \mathrm{mol}^{-1}$ were maintained by either adding pure $\mathrm{CO}_{2}$, or air which had been scrubbed of $\mathrm{CO}_{2}$ under the control of infrared $\mathrm{CO}_{2}$ analyzers which sampled air from each chamber continuously. Light was provided by a mixture of $400 \mathrm{~W}$ high pressure sodium and metal halide lamps at $1000 \mu \mathrm{mol}^{-2} \cdot \mathrm{s}^{-1}$ of photosynthetically active radiation. Plants were grown in 2 liter plastic pots filled with vermiculite and flushed once or twice per day with a complete nutrient solution. Four different chambers were used, with $\mathrm{CO}_{2}$ treatments rotated among chambers. For each photoperiod, there were two chambers at low and two at elevated $\mathrm{CO}_{2}$. There were five pots per isoline in each chamber, with one plant per pot. Environmental conditions in the chambers were logged every 15 minutes, and calibration of light, temperature and humidity sensors was performed at the beginning and end of each experiment. The calibration of the $\mathrm{CO}_{2}$ analyzers was checked weekly. Vegetative and reproductive stages were recorded for every plant every 1 to 3 days until a flower opened on the mainstem of that plant. Each of the 4 photoperiod by $2 \mathrm{CO}_{2}$ treatments conditions was re- 
peated in different chambers, and statistical comparisons are based on $n=2$ chamber replicates per treatment. The number of days between the unfolding of the $5^{\text {th }}$ and $12^{\text {th }}$ mainstem leaves was also recorded for each plant.

\section{Results}

In the glasshouse and field experiments, the E1e3E4 isoline never flowered, so is not considered further in these experiments. Of the other five isolines in the glasshouse experiment, the e1e3e4 isoline had first flowering (R1) delayed by elevated $\mathrm{CO}_{2}$, while R1 was earlier at elevated $\mathrm{CO}_{2}$ in the e1E3e4 isoline, and was unaffected by $\mathrm{CO}_{2}$ in the three other isolines (Table 2). The number of days between R1 and R5 was increased by elevated $\mathrm{CO}_{2}$ in the e1e3e4 and isoline, but was not affected by $\mathrm{CO}_{2}$ in the other isolines (Table 2). Flowering at the apical main stem node was also delayed by elevated $\mathrm{CO}_{2}$ in the e1e3e4 isoline, and the number of main stem nodes at maturity was increased by elevated $\mathrm{CO}_{2}$ only in the e1e3e4 isoline (Table 2).

The field experiments produced very nearly the same patterns of flowering responses to $\mathrm{CO}_{2}$ as observed in the glasshouse (Table 3), although each developmental stage was slightly delayed in the field compared with the glasshouse experiment. The mean temperature was $23.7^{\circ} \mathrm{C}$ in the field during the experimental period. The R1

Table 2. Flowering characteristics and final main stem node numbers of soybean isolines grown in glasshouses at ambient (A) and elevated (E) $\mathrm{CO}_{2}$. Days refer to days from planting.

\begin{tabular}{|c|c|c|c|c|c|}
\hline Isoline & $\mathrm{CO}_{2}$ & $\begin{array}{c}\mathrm{R} 1 \\
\text { (days) }\end{array}$ & $\begin{array}{l}\text { R1 to R5 } \\
\text { (days) }\end{array}$ & $\begin{array}{c}\text { Flowering at apex } \\
\text { (days) }\end{array}$ & Main stem nodes \\
\hline \multirow{2}{*}{ e1e3e4 } & A & $24.8^{*}$ & $14^{*}$ & $41.0^{*}$ & $13.8^{*}$ \\
\hline & $\mathrm{E}$ & 25.8 & 17 & 44.8 & 15.8 \\
\hline \multirow{2}{*}{ e1e3E4 } & A & 27.6 & 18 & 48.4 & 15.6 \\
\hline & $\mathrm{E}$ & 27.4 & 18 & 49.0 & 16.0 \\
\hline \multirow{2}{*}{ e1E3e4 } & A & $27.6^{*}$ & 23 & 46.6 & 16.0 \\
\hline & $\mathrm{E}$ & 25.6 & 23 & 47.0 & 15.6 \\
\hline \multirow{2}{*}{ E1e3e4 } & A & 29.8 & 26 & 45.4 & 15.4 \\
\hline & $\mathrm{E}$ & 30.0 & 26 & 46.0 & 15.8 \\
\hline \multirow{2}{*}{ e1E3E4 } & A & 30.2 & 25 & 51.6 & 17.8 \\
\hline & $\mathrm{E}$ & 29.8 & 26 & 52.6 & 18.6 \\
\hline
\end{tabular}

${ }^{*}$ indicates a significant effect of $\mathrm{CO}_{2}$ concentration at $\mathrm{P}=0.05$ for that isoline, based on $\mathrm{n}=5$ plants in each glasshouse.

Table 3. Flowering characteristics and final main stem node numbers of soybean isolines grown in the field at ambient (A) and elevated (E) $\mathrm{CO}_{2}$. Days refer to days from planting.

\begin{tabular}{|c|c|c|c|c|c|}
\hline Isoline & $\mathrm{CO}_{2}$ & $\begin{array}{c}\mathrm{R} 1 \\
\text { (days) }\end{array}$ & $\begin{array}{l}\text { R1 to R5 } \\
\text { (days) }\end{array}$ & $\begin{array}{c}\text { Flowering at apex } \\
\text { (days) }\end{array}$ & Mainstem nodes \\
\hline \multirow{2}{*}{ e1e3e4 } & A & $32.1^{*}$ & $17^{*}$ & $49.0^{*}$ & $15.0^{*}$ \\
\hline & E & 33.2 & 19 & 51.8 & 16.5 \\
\hline \multirow{2}{*}{ e1e3E4 } & A & 37.3 & 19 & 56.2 & 18.5 \\
\hline & E & 37.4 & 19 & 56.6 & 18.2 \\
\hline \multirow{2}{*}{ e1E3e4 } & A & $36.6^{*}$ & 19 & 58.8 & 20.3 \\
\hline & E & 35.6 & 20 & 57.9 & 20.5 \\
\hline \multirow{2}{*}{ E1e3e4 } & A & 41.0 & 16 & 57.0 & 20.2 \\
\hline & $\mathrm{E}$ & 41.9 & 15 & 56.5 & 19.7 \\
\hline \multirow{2}{*}{ e1E3E4 } & A & 41.2 & 18 & 62.1 & 18.3 \\
\hline & E & 40.8 & 18 & 62.5 & 18.6 \\
\hline
\end{tabular}

\footnotetext{
${ }^{*}$ indicates a significant effect of $\mathrm{CO}_{2}$ concentration at $\mathrm{P}=0.05$ for that isoline, based on 3 replicate plots per $\mathrm{CO}_{2}$ treatment.
} 
stage and the time of flowering at the apical node were delayed by elevated $\mathrm{CO}_{2}$ only in the e1e3e4 isoline, and $\mathrm{R} 1$ was earlier at elevated $\mathrm{CO}_{2}$ in the e1E3e4 isoline. Final mainstem node number was increased by elevated $\mathrm{CO}_{2}$ only in the e1e3e4 isoline (Table 3).

The time to R1 in the glasshouse for each $\mathrm{CO}_{2}$ and isoline agreed quite well with the results from the indoor chambers, if one assumes a photoperiod of between 15.5 and 16 hours in the glasshouse (Figure 1). This would be consistent with photoperiod corresponding approximately to the duration of Civil Twilight at Beltsville for the glasshouse experimental period. Civil Twilight ranged from $15 \mathrm{~h} 50$ minutes to $15 \mathrm{~h} 59$ minutes

(http://aa.usna.navy.mil/cgi-bin/aa_rstablew.pl) between planting and day 32, which was the last date of reaching R1 for these isolines.

In the indoor chamber experiments, the effect of $\mathrm{CO}_{2}$ concentration on the time to $\mathrm{R} 1$ varied among isolines, and for all isolines there was a significant interaction between $\mathrm{CO}_{2}$ and photoperiod as determined by ANOVA (Figure 2). Elevated $\mathrm{CO}_{2}$ delayed $\mathrm{R} 1$ in e1e3e4 by slightly more than a day at both the 11 and 17 hour photoperiods, but not at the intermediate photoperiods. In e1e3E4 elevated $\mathrm{CO}_{2}$ delayed R1 with 11 hour days, but accelerated R1 at 15 and 17 hours. Elevated $\mathrm{CO}_{2}$ delayed R1 by 1.2 to 1.6 days in E1e3e4 at the three shorter photoperiods, but accelerated it by 2 days at the longest photoperiod. The largest $\mathrm{CO}_{2}$ effects were in e1E3e4, where elevated $\mathrm{CO}_{2}$ accelerated $\mathrm{R} 1$ by 3.6 days with the 17 hour photoperiod, and in e1E3E4, where elevated $\mathrm{CO}_{2}$ delayed R1 by 3 days at the shortest photoperiod (Figure 2). At the shortest photoperiod, elevated $\mathrm{CO}_{2}$ delayed R1 in five of the six isolines. In most cases when e1 was present, the time to R1 was longer for the 11 than for the 13 hour photoperiod, whereas when E1 was present, R1 occurred either at the same time or earlier at the 11 than at the 13 hour photoperiod (Figure 2). The mean number of days between the unfolding of mainstem leaves 5 and 12 was $14.0 \pm 0.3$ days for all isolines, photoperiods, and $\mathrm{CO}_{2}$ treatments.

\section{Discussion}

There was no replication of the glasshouse environments in this study. However, the responses of flowering times to the $\mathrm{CO}_{2}$ treatments observed in the glasshouse were consistent with the patterns observed in the field tests, which were replicated, and also fit well with the patterns of flowering in response to photoperiod length in the indoor chambers, which were also replicated. The effect of $\mathrm{CO}_{2}$ on flowering time of each isoline observed in the glasshouse was predictable from the responses observed in the indoor chambers with the assumption of a photoperiod of 15.5 to 16 hours in the glasshouse. Based on these plant responses, and the frequent recording of environmental conditions, it is unlikely that actual experimental conditions in the glasshouses varied significantly from the programmed conditions.

It is clear that each of the three of the photoperiod genes studied resulted in an effect of $\mathrm{CO}_{2}$ on flowering time. This is shown by the earlier flowering at elevated $\mathrm{CO}_{2}$ in all three of the single dominant gene isolines when grown at the 17 hour photoperiod, which contrasts with the later flowering at elevated $\mathrm{CO}_{2}$ in the all recessive isoline at the same photoperiod. When these dominant photoperiod genes were ineffective in delaying flowering because of being grown at the shortest photoperiod, all but one of the isolines had slower flowering at elevated $\mathrm{CO}_{2}$. At the intermediate photoperiods, $\mathrm{CO}_{2}$ consistently affected flowering only in E1, which suggested that E1 required a longer photoperiod for elevated $\mathrm{CO}_{2}$ to switch from delaying to accelerating flowering than occurred in the other single dominant isolines. Faster flowering at elevated $\mathrm{CO}_{2}$ for long photoperiods means that elevated $\mathrm{CO}_{2}$ makes these photoperiod sensitive genes less effective. Elevated $\mathrm{CO}_{2}$ could possibly speed flowering time by increasing the overall rate of plant development by increasing energy supply. However, at the shortest photoperiod, when such an effect would be magnified, elevated $\mathrm{CO}_{2}$ actually slowed flowering in all isolines. Additionally, no effect of $\mathrm{CO}_{2}$ concentration on the rate of leaf initiation occurred at any photoperiod. Tissue warming by elevated $\mathrm{CO}_{2}$ may also occur due to reduced transpiration and could affect overall rates of development. However, this is not consistent with the observed slowing of flowering by elevated $\mathrm{CO}_{2}$ at short photoperiods.

The E3 and E4 genes are known to be related to two different forms of phytochrome A [5]. The E3 and E4 genes have been reported to slow the progression of flowering after R1 in addition to delaying R1 [8] [9], while E1 only delayed R1. In our glasshouse data, this distinction among E1 and E3 and E4 was not reflected in the days between R1 and R5, but was reflected in the days to flowering at the apex, which was longer for e1E3e4, e1e3E4 and especially e1E3E4 than it was for E1e3e4. However, elevated $\mathrm{CO}_{2}$ did not affect either the days between R1 and R5, or the days to flowering at the apex in any of the isolines which had at least one dominant 

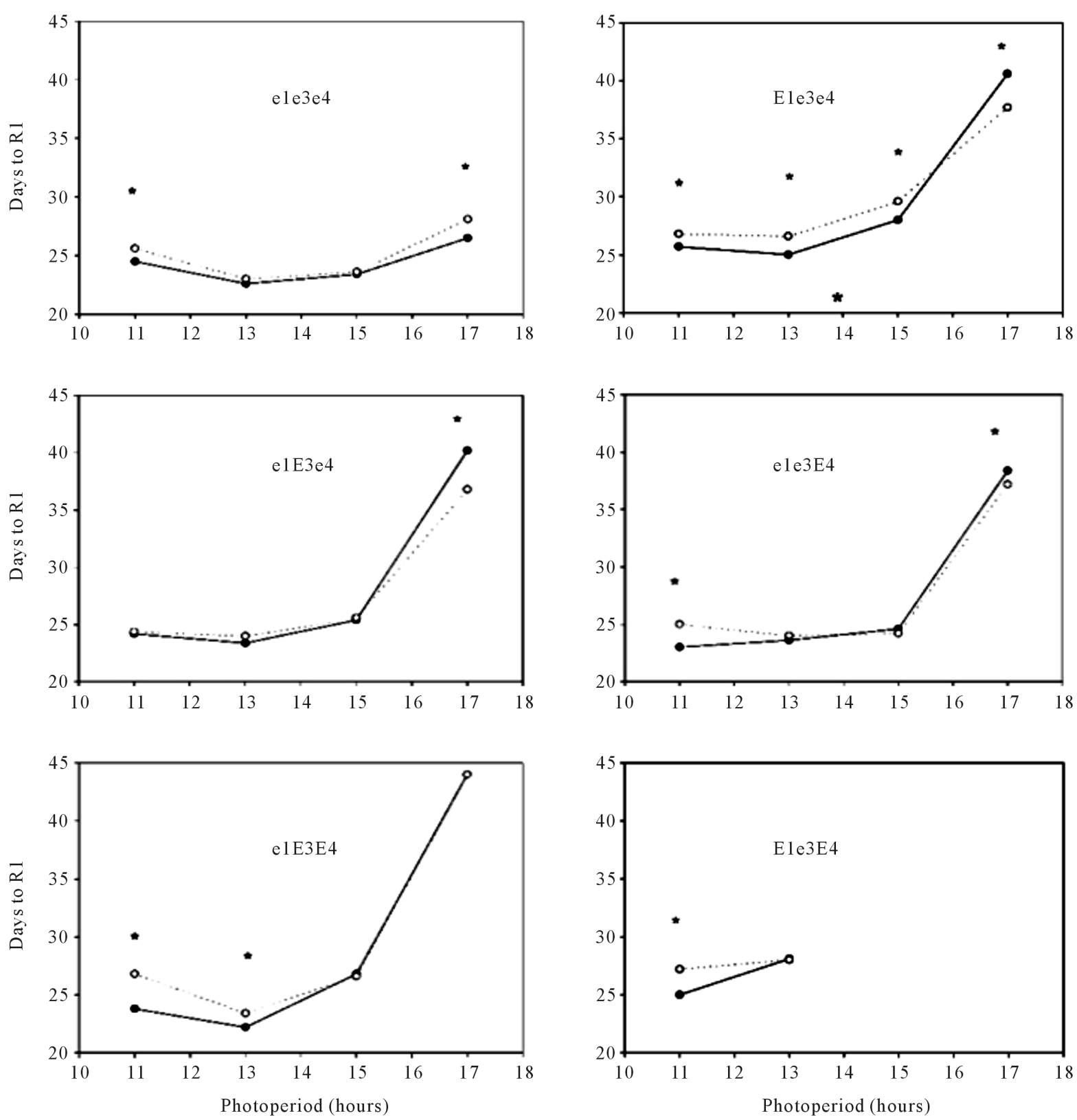

Figure 2. Days to first open flower (R1) in soybean isolines grown with four photoperiods at 380 (filled symbols) or 560 (open symbols) $\mu \mathrm{mol} \cdot \mathrm{mol}^{-1}$ daytime $\mathrm{CO}_{2}$ concentrations in indoor chambers. * indicates a significant effect of $\mathrm{CO}_{2}$ concentration at that photoperiod, based on $\mathrm{n}=2$ chambers per treatment.

allele. In Arabidopsis thaliana, two different phytochrome B mutants showed $\mathrm{CO}_{2}$ effects on the leaf number at flower bud formation when grown with a short photoperiod [10], but the phytochrome A mutant tested showed no effect of $\mathrm{CO}_{2}$ on flowering. There was a strong interaction between photoperiod and $\mathrm{CO}_{2}$ in their effects on flowering in Arabidopsis thaliana wild type and photoperiod mutants [10], as found here in soybean.

In our prior work with other soybean cultivars [1], there was no correlation between $\mathrm{CO}_{2}$ effects on the time of first flowering and the rate of progression through flowering stages, and the time of flowering at the apical node and the number of main stem nodes at maturity. However, in this comparison of photoperiod isolines all within one cultivar, these responses were all correlated with each other in the glasshouse and field experiments, with elevated $\mathrm{CO}_{2}$ delaying flowering in the all recessive isoline, increasing the days between $\mathrm{R} 1$ and $\mathrm{R} 5$, increasing the days to first flowering at the apical main stem node, and increasing the final number of main stem 
nodes in both the glasshouse and in the field. While an increase in main stem nodes from about 15 to 17 observed here in the all recessive isoline may seem too small to have much impact on seed yield, often in field situations there are no pods on the lowest 5 or more nodes, and often no axillary branches, so the total number of pods could be increased by about $20 \%$ just by the delay in flowering observed at elevated $\mathrm{CO}_{2}$. Previous work with different soybean cultivars in the field indicated a strong correlation between the increase in main stem node number at elevated $\mathrm{CO}_{2}$ and the increase in seed yield (Bunce, 2015).

These experiments did not indicate why elevated $\mathrm{CO}_{2}$ slowed flowering at short photoperiods, since nearly all of the isolines tested responded similarly to $\mathrm{CO}_{2}$ at short photoperiods. However, these experiments indicated that the E1, E3 and E4 genes all caused faster flowering at elevated $\mathrm{CO}_{2}$ at the longest photoperiod used. The $\mathrm{E} 1, \mathrm{E} 3$ and $\mathrm{E} 4$ isolines varied in the effect of $\mathrm{CO}_{2}$ on flowering time at intermediate photoperiods. Variation among soybean cultivars in these photoperiod genes could be a source of variation in effects of elevated $\mathrm{CO}_{2}$ on flowering phenology and possibly on yield.

\section{References}

[1] Bunce, J.A. (2015) Elevated $\mathrm{CO}_{2}$ Effects on Reproductive Phenology and Seed Yield among Soybean Cultivars. Crop Science, 55, 339-343. http://dx.doi.org/10.2135/cropsci2014.04.0273

[2] Ellis, R.H., Crauford, P.Q., Summerfield, R.J. and Roberts, E.H. (1995) Linear Relations between Carbon Dioxide Concentration and Rate of Development towards Flowering in Sorghum, Cowpea and Soybean. Annals of Botany, 75 , 193-198. http://dx.doi.org/10.1006/anbo.1995.1012

[3] Springer, C.J. and Ward, J.K. (2007) Flowering Time and Elevated Atmospheric $\mathrm{CO}_{2}$. New Phytologist, 176, $243-255$. http://dx.doi.org/10.1111/j.1469-8137.2007.02196.x

[4] Cober, E.R., Tanner, J.W. and Voldeng, H.D. (1996) Genetic Control of Photoperiod Response in Early-Maturing, Near-Isogenic Soybeans Lines. Crop Science, 36, 601-605. http://dx.doi.org/10.2135/cropsci1996.0011183X003600030013x

[5] Cober, E.R. and Morrison, M.J. (2010) Regulation of Seed Yield and Agronomic Characters by Photoperiod Sensitivity and Growth Habit Genes in Soybean. Theoretical and Applied Genetics, 120, 1005-1012. http://dx.doi.org/10.1007/s00122-009-1228-6

[6] Cober, E.R., Tanner, J.W. and Voldeng, H.D. (1996b) Soybean Photoperiod-Sensitivity Loci Respond Differentially to Light Quality. Crop Science, 36, 606-610. http://dx.doi.org/10.2135/cropsci1996.0011183X003600030014x

[7] Fehr, W.R., Caviness, C.E., Burmood, D.T. and Pennington, J.S. (1971) Stage of Development Descriptions for Soybeans, Glycine max (L.) Merr. Crop Science, 11, 929-931. http://dx.doi.org/10.2135/cropsci1971.0011183X001100060051x

[8] McBain, B.A., Hesketh, J.D. and Bernard, R.L. (1987) Genetic Effects on Reproductive Phenology in Soybean Isolines Differing in Maturity Genes. Canadian Journal of Plant Science, 67, 105-116. http://dx.doi.org/10.4141/cjps87-012

[9] Saindon, G. Beversdorf, W.D. and Voldeng, H.D. (1989) Adjustment of the Soybean Phenology Using the E4 Locus. Crop Science, 29, 1361-1365. http://dx.doi.org/10.2135/cropsci1989.0011183X002900060006x

[10] Song, X., Kristie, D.N. and Reekie, E.G. (2008) Why Does Elevated $\mathrm{CO}_{2}$ Affect Time of Flowering? An Exploratory Study Using the Photoperiodic Flowering Mutants of Arabidopsis thaliana. New Phytologist, 181, 339-346.

http://dx.doi.org/10.1111/j.1469-8137.2008.02669.x 